\title{
URAEMIA IN MYELOMATOSIS
}

\author{
By K. J. GurLING, M.D., M.R.C.P. \\ Associate in Medicine, Hospital of the University of Pennsylvania, Philadelphia
}

Renal failure with nitrogen retention and toxic inhibition of erythropoiesis is a well recognized cause of normochromic anaemia.

In myelomatosis, however, anaemia is due to a primary disorder of bone marrow and kidney damage develops secondarily. A minor degree of renal insufficiency is often encountered in multiple myeloma, the blood urea being raised in 25.5 per cent. of patients according to Meacham (1953), and in 57 per cent. of the series reported by Adams et al. (1949). Severe uraemia is less frequent and death is usually due to malignant cachexia and anaemia rather than to uraemia.

Four patients whose histories are reported died of renal failure with definite signs of uraemia, thus emphasizing the need to consider myelomatosis in the differential diagnosis when anaemia and uraemia are associated.

\section{Case Histories}

\section{Case I}

A man, aged 43, complained of lethargy, dyspnoea, vomiting and headache of three months' duration. Six months previously albuminuria had been discovered at another hospital during investigation of frequency of micturition and vague pains in the groins. When examined he was very anaemic, Hb., 32 per cent., had a uriniferous smell and appeared to be uraemic due to chronic nephritis. The urine not only contained albumin but also Bence-Jones protein as well as hyaline and granular casts, and his blood urea was $275 \mathrm{mg}$. per $100 \mathrm{ml}$. The bone marrow contained myeloma cells and X-rays of the skull showed characteristic discrete areas of rarefaction. Total serum proteins were $53 \mathrm{~g}$. per $100 \mathrm{ml}$., with albumin $4.7 \mathrm{~g}$ and globulin $0.6 \mathrm{~g}$. The blood urea rose to $515 \mathrm{mg}$. in ten days; he became more uraemic with muscular twitching, cramps, nausea and vomiting and after 48 hours of anuria died in coma.

Post-mortem. There were typical changes of myelomatosis in the bone marrow. The kidneys were normal in size and there were scattered irregular pale areas in the cortex. Microscopically the glomeruli appeared normal and in the inter- stitial tissue there were areas of infiltration with lymphocytes and plasma cells. Almost all the tubules contained eosinophilic hyaline casts in their distal portions. The tubular epithelium showed areas of proliferation which in some places had become detached and adherent to the casts, whilst in others there appeared to be pressure atrophy.

\section{Case 2}

A 46-year-old man had pains in the thoracic and lumbar spine for nearly a year before he was found to be anaemic with $\mathrm{Hb}$. 68 per cent. A peripheral blood film revealed plasma cells; a bone marrow biopsy confirmed the diagnosis of myelomatosis and $\mathrm{X}$-rays showed generalized rarefaction of bone with partial collapse of a lumbar vertebra and osteolytic nodules in the skull. Bence-Jones protein and granular casts were present in the urine and the blood urea was 1 ro $\mathrm{mg}$. per $100 \mathrm{ml}$. The total serum proteins were $7.8 \mathrm{~g}$. per $100 \mathrm{ml}$., with albumin $3.6 \mathrm{~g}$. and globulin $4.2 \mathrm{~g}$. Within five weeks of admission the blood urea had risen to $435 \mathrm{mg}$.; he became increasingly drowsy and after several blood transfusions died in uraemia.

Post-mortem. The vertebrae, ribs, pelvis and long bones were widely involved. Both kidneys appeared pale and a little large. Microscopically there were numerous eosinophilic casts in the tubules, some appearing laminated. The tubular epithelium had undergone proliferation in places but there were no obvious areas of atrophy and the interstitial tissue was normal. There was also a mild degree of arteriosclerotic fibrous obliteration of the glomeruli.

\section{Case 3}

Two years before admission this 65-year-old woman developed vague pains in the limbs and joints together with a normochromic anaemia and had been treated for ' rheumatoid arthritis' without benefit. She now had pain in the sacrum relieved only by lying flat, a small pleural effusion and anaemia with $\mathrm{Hb} .5^{8}$ per cent. The urine 
contained albumin but Bence-Jones protein was never detected. The peripheral blood showed a tendency of the red cells to rouleaux formation, there were occasional plasma cells and a bone marrow biopsy revealed typical myeloma cells.

The blood urea rose from I $95 \mathrm{mg}$. per $100 \mathrm{ml}$. to $390 \mathrm{mg}$. within ten days and she died in uraemic coma with hiccup and acidotic respiration.

Post-mortem. The bone marrow was riddled with myeloma tissue containing plasma and multinucleated cells. Both kidneys were coarsely granular with ill-defined whitish areas in the cortex. Microscopically there were changes indicating myelomatosis and pyelonephritis. There were numerous tubular casts to which the epithelium was adherent, in some places giving rise to the appearance of giant cells. The glomeruli were also obliterated in patches and there were polymorphs and round cells in the interstitial tissue. Renal failure may not, therefore, have been entirely due to myeloma nephropathy.

\section{Case 4}

A woman, aged 68 years, complained of tiredness and was found to have a normochromic anaemia with $\mathrm{Hb} .5^{6}$ per cent. A routine marrow biopsy revealed the presence of myeloma cells ranging from plasma cells to bizarre multinucleated forms, and this was the only indication of the true diagnosis.

The total serum proteins were normal at $6.4 \mathrm{~g}$. per $100 \mathrm{ml}$., and the urine contained no abnormal constituents on repeated examinations.

She was treated with multiple blood transfusions and a year later the urine was found to contain granular casts and, intermittently, Bence-Jones protein. The blood urea was unexpectedly found to be $190 \mathrm{mg}$. per $100 \mathrm{ml}$. and she died of uraemia with blood urea of $400 \mathrm{mg}$. 16 months after diagnosis.

Post-mortem. There were signs of essential hypertension and a moderate degree of arteriosclerosis of the aorta and renal arteries. The bone marrow had been replaced by myeloma tissue. The kidneys showed little naked eye change, but histologically the tubules were full of hyaline material to which the epithelium was adherent in places, with atrophic changes in other areas. The interstitial tissue showed definite round and plasma cell infiltration.

\section{Discussion}

Myelomatosis can be considered a neoplastic disease affecting the bone marrow which is replaced by abnormal tissue containing a variety of plasma-type cells, but extraosseous tumours may also occur. The clinical manifestations are often bizarre and include bone pain, vertebral collapse and anaemia, descriptions of which have been given by Lumb (195I) and Schwartz and Cataldoํ. (1953).

The renal changes are not usually of importance but Lohlein (1921) and Bannick and Greene (1929) drew attention to clinical evidence of impaires function usually of a mild degree. Bell (1933) later described the characteristic histologicas picture as myeloma nephrosis.

\section{Pathological Changes in the Kidney}

There may be very little naked eye change other than slight enlargement and pallor, coupled with non-specific arteriosclerotic scarring, localized $\vec{\omega}$ myeloma deposits being rare. Should there alson be chronic pyelonephritis as in Case 3, there mayg be granularity of the cortex and reduction in size of one or both kidneys.

The microscopic appearance is more obviouslyw abnormal with the tubules bearing most of the damage, as in all these four cases. The distal partsi of the tubules contain structureless hyaline casts 0 presumably of Bence-Jones protein, which sometimes appear to occlude the lumina completely $\vec{c}$ These casts are often broken into concentriç laminae during preparation and occasionally contain granules of calcium. According to Sikl (1949) and Neumann (1949) elongated crystals of protejno up to $30 \times 80 \mu$ in size also may be found embedded in the casts, lying free in the tubular lumen or the glomeruli, but such changes are rare.

The tubular epithelium is also damaged and shows areas of atrophy and of regenerationo apparently secondary to pressure and irritationo caused by the protein casts. In some places the epithelium becomes detached, lying free in theo lumen or adherent to the casts to give the impression of foreign body giant cells, which Allen (1952) has shown in fact to be syncitial masses of fused epithelium. A few cases show scattered foci of calcification in the tubular epithelium giving. rise to the picture of nephrocalcinosis. Infiltration 3 . of the interstitial tissue with polymorphs andi particularly round cells and plasma cells is com- 3 mon, as in Cases I and 4, quite apart from the pyelonephritic picture seen in Case 3. 'The glomeruli show no definite changes other thano obliteration due to pyelonephritis or arteriosclerosis, and neither thickening of the basemento membrane nor crystal formation are often visible. N

\section{Pathogenesis of the Renal Lesions}

Elevation of the serum proteins to levels of 10 to $15 \mathrm{~g}$. per $100 \mathrm{ml}$. is not unusual in myelomatosis, but whether this is due to occult infection, liveres disease or to the metabolism of the myeloma cells is uncertain. Even when the total serum proteino is normal the globulin fraction may be high and 
the electrophoretic pattern abnormal with alpha and gamma globulins of unusual type (Blackman et al., 1944; Adams et al., 1949). In only one of the present cases were the globulins significantly elevated, but Adams et al. (1949) found the total proteins elevated above $8.0 \mathrm{~g}$. in 52 per cent. with abnormalities in the electrophoretic patterns in all cases. Bence-Jones protein is probably derived from these plasma globulins but proof is lacking and there is no clear correlation between the degree of Bence-Jones proteinuria and plasma globulin levels. Thus Stewart and Weber (1938) and Rundles et al. (195I) found the two unrelated, whilst Meacham (1953) considered Bence-Jones proteinuria most likely to occur when the plasma globulins were elevated. The molecular weight of globulin is in the region of 156,000 and that of Bence-Jones protein, which is of inconstant composition and varying antigenic and electrophoretic properties, lies between 25,000 and 64,000 with a mean of 35,000 (Moore et al., 1943; Blackman et al., 1944; Rundles et al., 195I). Bence-Jones proteins cannot be identified in the serum and may well arise from incompletely elaborated globulins with a sufficiently small molecular size to pass the glomerular filter in the absence of any readily discernible glomerular abnormality. Once in the tubules. absorption of water produces a concentration which, if excretion is long continued, leads to the deposition of casts. Nevertheless histological changes may be considerable in the absence of Bence-Jones proteinuria, as in Case 3, the incidence of which has been variously reported from as low as 8 per cent. of patients by Coley (I93I) to 75 per cent. by Magnus Levy (1937), with a mean of about 47 per cent. as noted by Adams et al. (1949). Obstruction of the tubules by casts appears to be the important factor in producing renal failure. Experimentally Forbus et al. (1935) found that Bence-Jones protein given intravenously to dogs was not specifically toxic to the tubular epithelium, but they concluded that long continued excretion accompanied by partial urinary obstruction might lead to the accumulation of casts. A mild degree of renal decompensation may be present without clinical manifestations, as shown by moderate elevation of the blood urea and impairment of tests of function. Armstrong (1950) reported a reduction in glomerular filtration rate in the absence of other evidence of renal damage, unrelated to the duration of the disease or presence of Bence-Jones proteinuria. On the other hand, Goldman et al. (1952) found significant impairment of both glomerular and tubular function indicating early involvement of the whole nephron. Histological studies do not provide evidence of glomerular damage, but the frequency of albuminuria, which : Schwartz and Cataldo found in
80 per cent. of their series as opposed to the 23 per cent. with Bence-Jones proteinuria, suggests that the glomerulus does not escape entirely.

\section{Differential Diagnosis}

Many of the common causes of renal failure may be simulated by myelomatosis and the diagnosis may be made difficult by the presence of albuminuria and casts. To detect Bence-Jones protein in such circumstances the urine should be boiled with a little acetic acid until the albumin is precipitated, filtered hot and the filtrate slowly reheated in a water bath to detect precipitation between $45^{\circ} \mathrm{C}$. and $65^{\circ} \mathrm{C}$. Alternatively, all protein may be precipitated by sulphosalicylic acid and the suspension boiled; if the precipitate is heavier when cool than on boiling, Bence-Jones protein is probably present. Bone marrow biopsy is of far greater diagnostic value, for in myelomatosis, unlike cases of anaemia due to nitrogen retention, there will be myeloma cells present which eventually replace the erythropoietic tissue. The peripheral blood shows a non-specific normochromic anaemia with a tendency to rouleaux formation, and plasma cells are seldom visible until the terminal stages. "Radiological examination of the bones, the skull in particular, will reveal generalized osteoporosis and circumscribed areas of rarefaction, and as already mentioned estimation of the serum proteins may be of help.

The presence of nephro-calcinosis can be miselading and a high serum calcium accompanied by osteoporosis may simulate parathyroid hyperplasia, as in the case reported by Cosgrove and La Tourette (1953).

Lastly, since the characteristic renal changes are present in a high proportion of cases, Greenwald et al. (1953) have suggested that needle biopsy of the kidney might be utilized to distinguish between myeloma kidney and other forms of glomerulo or pyelonephritis.

\section{Treatment}

It is unlikely that any form of therapy will restore renal function once protein casts have been deposited, and uraemia can develop surprisingly quickly. There is no good evidence that stilbamidine as recommended by Snapper (1946) is effective, and two of Brewer's (1948) cases died with renal failure in spite of treatment. Similarly, urethane, myleran, radiotherapy and ACTH have never been proved effective and at their best can only relieve bone pain and alleviate anaemia temporarily. The presence of Bence-Jones protein is a warning that renal failure is possible but uraemia can certainly develop in its absence. 


\section{Summary}

I. The histories of four cases of myelomatosis are reported in which death occurred in uraemia.

2. The pathogenesis of the renal lesion is discussed.

3. The need to distinguish the renal and haematological manifestations. of myelomatosis from other forms of renal failure with secondary anaemia is emphasized.

\section{BIBLIOGRAPHY}

ADAMS, W. S., ALLING, E. L., and LAWRENCE, J. S. (1949), Amer. $\mathcal{~ . ~ M e d . , ~ 6 , ~} 141$.

ALLEN, A. C. (1952), 'The Kidney,' Churchill, London.

ARMSTRONG, J. B. (1950), Amer. F. Med. Sci., 219, 489.

BANNICK, E. G., and GREENE, C. H. (1929), Arch. int. Med., 44, 486.

BELL, E. T. (1933), Am. F. Path., 9, 393.

BLACKMAN, S. S., BARKER, W. H., BUELL, M. V., and DAVIS, B. D. (1944), F. Clin. Invest., 23, I63.
BREWER, A. E. (1948), Brit. med. F., ii, 978.

COLEY, W. B. (1931), Ann. Surg., 93, 77.

COSGROVE, K. E., and LA TOURRETTE, K. A. (1953), Ame F. Med., 15, 862 .

FORBUUS, W. D., PERLZWEIG, W. A., PARFENTIEV, I. A음 and BURWELL, J. C. (1935), Bull. Fohns Hopk. Hosp., 57, 4\%'

GOLDMAN, R., ADAMS, W. S., and LUCHSINGER, E. B. (1952), F. Lab. clin. Med., 40, 519.

GREENWALD, H. P., BRONFIN, G. J., and AUERBACH, 0 (1953), Amer. $\mathcal{F}$. Med., $15,198$.

LOHLEIN, M. (1921), Beitr. Path. Anat., 69, 295.

LUMB, G. (1952), Ann. Roy. Col. Surg., 10, 241.

MAGNUS-LEVY, A. (1933), Ztschr. f. klin. Med., 126, 62.

MEACHAM, E. A. (1953), Ann. int. Med., 38, 1035.

MOORE, D. H., KABAT, E. A., and GUTMAN, A. B. (1943d F. Clin. Invest., 22, 67 .

NEUMANN, V. (1950), Ұ. Path. Bact., 61, 165.

RUNDLES, R. W., COOPER, G. R., and WILLETT, R. (I95 I), Amer. F. Med., II, 249.

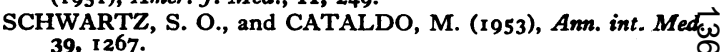

SIKL, H. A. (1949), F. Path. Bact., 6r, 149.

SNAPPER, I. (1946), Ұ. Mt Sinai Hosp., 13, 119.

STEWART, A., and WEBER, F. P. (1938), Quart. f. Med., 7, 2 1.

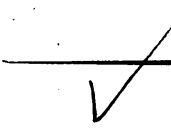 \\ INTRAPERITONEAL RUPTURE OF AN AMOEBIC ABSCESS OF THE LIVER}

By J. B. SelF, F.R.C.S.

Formerly R.S.O. at Fersey General Hospital.

Rupture of an amoebic abscess of the liver into the general peritoneal cavity is uncommon, very few cases being recorded in the literature and none from the British Isles. The following case is therefore reported.

\section{Case Record}

A well-built man of 37 was admitted on May 8, 1952, with severe epigastric pain for previous eight hours.

He had a long history of amoebic dysentery and hepatitis, beginning with a short attack of dysentery in Assam in 1944. In 1945 he was invalided home. Whilst on the troopship he had a severe attack of dysentery. He spent two periods in hospital of about four weeks on arrival in the United Kingdom. Amotbae were found in his stools at that time. He was demobilised at the end of 1945. In 1947 he was in the Jersey General Hospital with pyrexia and constipation, and again in 1949, with sweats and abdominal pain.

In February 1952 he was admitted to Roe- hampton Hospital complaining of abdominal pain $\overrightarrow{\vec{P}}$ sweats, pyrexia and constipation. Amoebae were found in his stools and his liver was enlarged A full course of anti-amoebic treatment was given and he was discharged in mid-April. He cons tinued to have vague abdominal discomfort untif his acute abdominal pain commenced on May 1952.

\section{Condition on Admission}

He had a sunken grey face. Pulse 128, respira? tion 24, and temperature 99. His abdomen was rigid but not board-like and slightly distended. Tenderness was maximal in his right hypochono drium. Dullness to percussion in his right iliad fossa and right flank was present. There was no diminution of liver dullness. The liver edge was not palpable. The release sign was positive There was no tenderness P.R. There were ng abnormal signs in the chest.

A diagnosis of perforated peptic ulcer was made with, in view of the past history, an alternative diagnosis of a ruptured amoebic abscess. 